\title{
Faktor-Faktor yang Mempengaruhi Minat Beli Smartphone LG G7 Thinq Pada Fans BTS di Jakarta Barat
}

\author{
Brilliani, Suherman Kusniadji, Lusia Savitri Setyo Utami \\ Brillianiwijaya10@gmail.com,Kusniadjiherman@gmail.com,Lusias@fikom.untar.ac.id \\ Fakultas Ilmu Komunikasi Universitas Tarumanaga
}

\begin{abstract}
The purpose of this research is to find out the effect of Brand Ambassador and Sales Promotion to Interest Buy of Smartphone LG G7 ThinQ. This research using marketing communication, sales promotion, brand ambassador and interest buy theory. This research also using quantitative method by survey method. The research technic is probability with simple random sampling approach, the number of respondent are 97 people. Data collection technique using a questionnaire and literature studies. This analysis requirements test uses validity, reability and normality tests. Data analysis using multiple correlation coefficients, coefficient of determination, multiple linear regression analysis, $T$ test and $F$ test. From the result of the research, it is found that brand ambassador and sales promotion affect the interest buy of smartphone LG G7 ThinQ.
\end{abstract}

Keywords: Brand Ambassador, Sales Promotion, Interest Buy, BTS

\begin{abstract}
Abstrak
Penelitian ini bertujuan untuk mengetahui pengaruh Penggunaan Brand Ambassador BTS dan Sales Promotion terhadap Minat Beli Smartphone LG G7 ThinQ. Teori yang dibahas dalam penelitian ini adalah komunikasi pemasaran, sales promotion, brand ambassador dan minat beli. Metode penelitian yang digunakan adalah metode kuantitatif dengan jenis metode survei. Teknik penelitian yang digunakan adalah probability dengan pendekatan simple random sampling, responden sebanyak 97 orang. Teknik pengumpulan data dengan menggunakan kuesioner dan studi kepustakaan. Uji persyaratan analisis menggunakan uji validitas, reliabilitas dan normalitas. Analisis data menggunakan koefisien korelasi berganda, koefisien determinasi, analisis regresi linier berganda, uji T dan uji F. Hasil dari penelitian ini ditemukan bahwa brand ambassador dan promosi penjualan mempengaruhi minat beli handphone LG G7 ThinQ.
\end{abstract}

Kata Kunci: Brand Ambassador, Promosi Penjualan, Minat Beli, BTS

\section{Pendahuluan}

Teknologi komunikasi dan informasi berkembang begitu cepat sehingga konsumen menjadi semakin selektif dalam memilih produk yang akan digunakan atau dikonsumsi. Di lingkungan pemasaran yang kompetitif ini serta banyaknya pesaing di bidang yang sama, komunikasi yang efektif di dalam pemasaran menjadi hal yang penting. Perusahaan saling berkompetisi untuk mengupayakan berbagai hal yang dapat dilakukan untuk mempromosikan merek mereka. Perusahaan memiliki tantangan yang dihadapi yaitu bagaimana memperkenalkan produk mereka kepada calon konsumen. Penggunaan brand ambassador merupakan salah satu cara bagi perusahaan mengiklankan produknya. 
Brand ambassador digunakan oleh perusahaan untuk menjadi simbolisasi guna mewakili perusahaan melalui produk yang ditawarkan. Menurut Lea Grenwood dalam Muhammad Ikhsan, dkk (2014), brand ambassador merupakan suatu alat yang digunakan oleh suatu perusahaan guna berkomunikasi dengan publik, untuk mengetahui bagaimana cara meningkatkan penjualan”. Saat ini industri film dan musik di Korea Selatan merupakan faktor awal lahirnya Korean Wave. Pengaruh musik Korean Pop atau kerap disebut K-Pop sudah memasuki banyak negara, khususnya negara-negara di Asia. Hal ini dapat dibuktikan dengan banyaknya para penggemar dari boygroup dan girlgroup Korea, termasuk di Indonesia. Selain dampak dalam bidang industri kesenian, $K$-Pop juga mampu memberikan pengaruh besar dalam industri bisnis. LG mengambil strategi serupa dengan memanfaatkan pengaruh korean wave ini untuk meningkatkan penjualan produk mereka. LG menggunakan BTS sebagai brand ambassador produk smartphone LG G7 ThinQ miliknya. LG memutuskan menggunakan BTS sebagai brand ambassador mereka karena sebelumnya memenangkan Top Social Artist 2018 Billboard Music Awards. Selain menggunakan BTS sebagai brand ambassador, LG juga menggunakan promosi penjualan dengan cara memberikan merchandise seperti photo card BTS, poster BTS, wallpaper dan special theme BTS yang dipersembahkan pada para penggemar ARMY. Untuk itu, penulis ingin mengetahui apakah metode penjualan yang digunakan LG pada produk LG G7 ThinQ memiliki pengaruh terhadap minat beli pada target konsumennya yakni fans BTS.

Menurut latar belakang tersebut, penulis merumuskan permasalahan menjadi "Pengaruh Penggunaan Brand Ambassador BTS dan Sales Promotion Terhadap Minat Beli Smartphone LG G7 ThinQ Pada Kalangan Fans BTS Di Jakarta Barat”. Penelitian ini juga memilik tujuan yaitu untuk mengetahui pengaruh brand ambassador BTS dan sales promotion terhadap minat beli smartphone LG G7 ThinQ pada kalangan fans BTS di Jakarta Barat. Teori yang digunakan dalam penelitian ini adalah komunikasi pemasaran, brand ambassador, promosi penjualan (kupon, penurunan harga, premium dan sampel), minat beli.

\section{Metode Penelitian}

Penelitian ini menggunakan pendekatan penelitian kuantitatif. Penelitian kuantitatif merupakan penelitian yang didasarkan oleh filsafat positivisme, yang digunakan untuk meneliti suatu populasi atau sampel tertentu (Sugiyono, 2013). Strategi penelitian yang digunakan adalah metode penelitian survei. Pada penelitian ini, penulis akan menggunakan teknik pengumpulan data melalui kuesioner. Kuesioner merupakan teknik pengumpulan data yang dilakukan dengan cara memberi seperangkat pertanyaan atau pernyataan tertulis kepada responden untuk dijawabnya. Selain menggunakan kuesioner, penulis juga akan menggunakan studi. Studi kepustakaan yang penulis gunakan disini adalah buku-buku referensi, laporan, dan jurnal.

Penelitian dilakukan dengan menyebar kuesioner kepada 97 responden di Jakarta Barat. Penulis menggunakan teknik penelitian probability sampling dengan menggunakan pendekatan simple random sampling. Setelah penyebaran kuesioner, penelitian ini akan menggunakan uji validitas, uji reabilitas dan uji normalitas. Pengujian analisis data ini akan dilakukan dengan program SPSS 21. 


\section{Hasil Temuan dan Diskusi}

Berdasarkan hasil kuesioner dengan 97 responden di Jakarta Barat, diperoleh hasil sebesar $85,6 \%$ atau sebanyak 83 responden yang berusia 12-25 tahun. Dengan hasil ini dapat disimpulkan bahwa mayoritas fans BTS merupakan kategori anak muda yang berusia antara 12-25 tahun. Dari 97 responden tersebut diperoleh juga mayoritas jenis kelamin yang mengidolakan BTS. Hasil menunjukkan bahwa dari 97 responden, 73 responden adalah wanita.

Hasil uji validitas brand ambassador BTS (Variabel X1), sales promotion (Variabel X2), dan minat beli (Variabel Y) dinyatakan valid karena nilai dari corrected item total correlation lebih besar dari nilai 0,2. Hasil uji reabilitas variabel brand ambassador memiliki angka 0.965, variabel sales promotion memiliki angka 0.881 , dan variabel minat beli memiliki angka 0.883 yang memiliki arti bahwa nilai Cronbach's Alpha dari brand ambassador, sales promotion dan minat beli adalah lebih dari 0.60 maka ketiga variabel ini terbukti reliabel.

Hasil uji normalitas menunjukan hasil tabel penelitian terlihat titik-titik menyebar di sekitar garis diagonal dan mengikuti arah garis diagonal yang menunjukkan bahwa data terdistribusi dengan normal (gambar 3.1).

Gambar 3.1 Hasil Uji Normalitas

\section{Normal P-P Plot of Regression Standardized Residual}

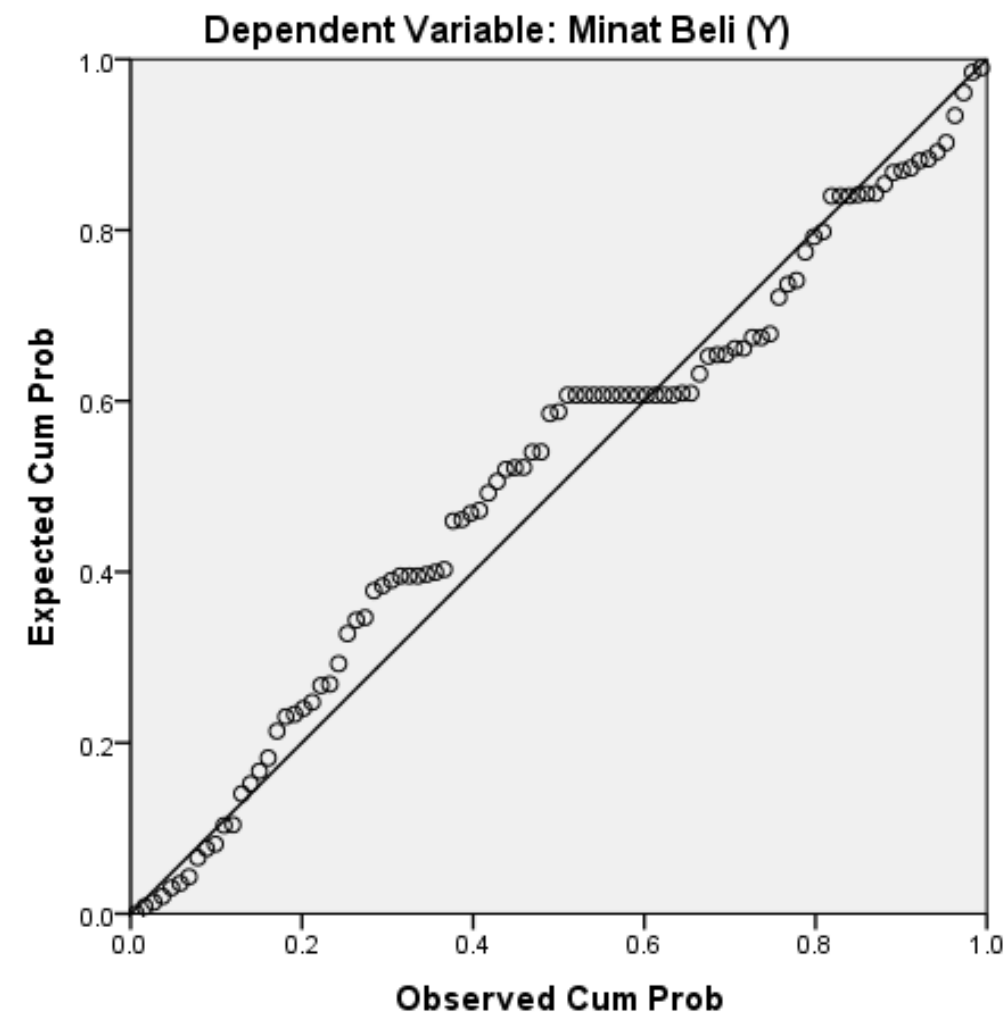

Uji koefisien korelasi (uji r) pada variabel brand ambassador (X1) dan sales promotion (X2) dan minat beli (Y) menunjukan Sig. F Change $0.000<0.05$, yang berarti memiliki hubungan korelasi. Dan nilai Pearson yaitu 0.846, berdasarkan data tersebut, dapat dikatakan bahwa hubungan pada variabel Brand Ambassador (X1) 
dan Sales Promotion (X2) dan Minat Beli (Y) adalah hubungan korelasi yang sempurna (Gambar 3.2)

Gambar 3.2 Hasil Uji Koefisien Korelasi

\begin{tabular}{|c|c|c|c|c|c|c|c|c|c|}
\hline \multirow{2}{*}{ Model } & \multirow{2}{*}{$\mathrm{R}$} & \multirow{2}{*}{$\begin{array}{c}\mathrm{R} \\
\text { N }\end{array}$} & \multirow{2}{*}{ Adjusted R Square } & \multirow{2}{*}{$\begin{array}{c}\text { Std. Error of } \\
\text { the Estimate }\end{array}$} & \multicolumn{5}{|c|}{ Change Statistics } \\
\cline { 5 - 9 } & & & & R Square Change & F Change & df1 & df2 & Sig. F Change \\
\hline 1 & $.846^{3}$ & .716 & .710 & 1.86250 & .716 & 118.399 & 2 & 94 & .000 \\
\hline
\end{tabular}

Uji koefisien determinasi (uji $\mathrm{r}^{2}$ ) menunjukan bahwa minat beli LG G7 ThinQ dipengaruhi sebesar 71,6\% oleh brand ambassador dan sales promotion, sementara sisanya $28,4 \%$ dipengaruhi oleh variabel-variabel lain.

Gambar 3.3 Hasil Uji Koefisien Determinasi Model Summary ${ }^{\mathrm{b}}$

\begin{tabular}{|l|r|r|r|c|}
\hline Model & \multicolumn{1}{|c|}{ R } & R Square & $\begin{array}{c}\text { Adjusted R } \\
\text { Square }\end{array}$ & $\begin{array}{c}\text { Std. Error of the } \\
\text { Estimate }\end{array}$ \\
\hline 1 & $.846^{\mathrm{a}}$ & .716 & .710 & 1.86250 \\
\hline
\end{tabular}

a. Predictors: (Constant), Sales Promotion (X2), Brand Ambassador (X1)

b. Dependent Variable: Minat Beli (Y)

Uji t menunjukkan bahwa pengaruh X1 terhadap Y adalah sebesar $0.000<0.05$ dan nilai t hitung $7.772>\mathrm{t}$ tabel 1.985 , sehingga dapat disimpulkan bahwa H1 diterima yang berarti terdapat pengaruh X1 terhadap Y. Diketahui nilai Sig. untuk pengaruh X2 terhadap $\mathrm{Y}$ adalah sebesar $0.000<0.05$ dan nilai $\mathrm{t}$ hitung $6.613>\mathrm{t}$ tabel 1.985, sehingga dapat disimpulkan bahwa $\mathrm{H} 2$ diterima yang berarti terdapat pengaruh X2 terhadap Y (gambar 3.4)

Gambar 3.4 Hasil Uji T

Coefficients $^{\mathrm{a}}$

\begin{tabular}{|ll|r|r|r|r|r|}
\hline \multirow{2}{*}{ Model } & \multicolumn{2}{|c|}{$\begin{array}{c}\text { Unstandardized } \\
\text { Coefficients }\end{array}$} & $\begin{array}{c}\text { Standardized } \\
\text { Coefficients }\end{array}$ & \multirow{2}{*}{ Sig. } & \\
\cline { 2 - 5 } & \multicolumn{1}{|c|}{$\mathrm{B}$} & Std. Error & \multicolumn{1}{c|}{ Beta } & & \\
\hline \multirow{2}{*}{1 (Constant) } & -1.589 & 1.199 & & -1.326 & .188 \\
Brand Ambassador (X1) & .224 & .029 & .517 & 7.772 & .000 \\
& Sales Promotion (X2) & .337 & .051 & .440 & 6.613 & .000 \\
\hline
\end{tabular}

a. Dependent Variable: Minat Beli (Y)

Dari uji $\mathrm{F}$ atau anova diperoleh hasil bahwa pengaruh $\mathrm{X} 1$ dan $\mathrm{X} 2$ terhadap $\mathrm{Y}$ adalah sebesar $0.000<0.05$ dan nilai $F$ hitung $118.399>\mathrm{F}$ tabel 3,09, sehingga dapat disimpulkan bahwa H3 diterima yang berarti terdapat pengaruh X1 dan X2 secara simultan terhadap Y (gambar 3.5) 
Gambar 3.5 Hasil uji F

\begin{tabular}{|c|c|c|c|c|c|c|}
\hline \multicolumn{2}{|c|}{ Model } & $\begin{array}{l}\text { Sum of } \\
\text { Squares }\end{array}$ & $\mathrm{df}$ & $\begin{array}{c}\text { Mean } \\
\text { Square }\end{array}$ & $\mathrm{F}$ & Sig. \\
\hline \multirow{3}{*}{1} & Regression & 821.429 & 2 & 410.715 & 118.399 & $.000^{b}$ \\
\hline & Residual & 326.076 & 94 & 3.469 & & \\
\hline & Total & 1147.505 & 96 & & & \\
\hline
\end{tabular}

a. Dependent Variable: Minat Beli (Y)

b. Predictors: (Constant), Sales Promotion (X2), Brand Ambassador (X1)

Dalam penelitian ini, penulis menggunakan analisis regresi linear berganda, karena variable bebas dalam penelitian ini lebih dari satu, yaitu brand ambassador dan sales promotion. Melalui uji ini diperoleh hasil $\mathrm{Y}=-1.589+0.224+0.337$ (gambar 3.6), dimana $\mathrm{Y}=$ Minat Beli dan X1 = Brand Ambassador dan X2 = Sales Promotion. Berdasarkan hasil diatas, dapat dijelaskan bahwa -1.589 merupakan nilai konstanta yang artinya jika pengaruh yang diberikan oleh variabel brand ambassador terhadap variabel minat beli sama dengan 0, maka nilai minat produk LG G7 ThinQ adalah sebesar -1.589. Selanjutnya adalah nilai koefisien regresi variabel brand ambassador (X1) yaitu sebesar 0.224, yang artinya bahwa peningkatan satu unit variabel periklanan dengan asumsi variabel bebas lain konstan akan menyebabkan kenaikan minat beli sebesar 0.224. Yang terakhir adalah koefisien regresi variabel sales promotion (X2) sebesar 0.337 , artinya bahwa peningkatan satu unit variabel periklanan dengan asumsi variabel bebas lain konstan akan menyebabkan kenaikan minat beli sebesar 0.337 .

\section{Simpulan}

Jumlah fans BTS memiliki nilai paling tinggi di kalangan mahasiswa, dalam variabel sales promotion penulis menghapus dimensi kupon karena LG tidak menggunakan kupon dalam pemasarannya terhadap LG G7 ThinQ. Korean Wave menjadi momen hangat di kalangan masyarakat di Indonesia maupun di internasional. Dengan adanya Korean Wave, para pengusaha menjadikan artis-artis Korea terkenal sebagai brand ambassador. Hal ini karenapenggemar fanatik memiliki keinginan kuat untuk membeli atau memakai barang yang sama dengan idolanya sehingga penggunaan brand ambassador sangatlah penting. Berdasarkan uji reliabilitas maka variabel brand ambassador yaitu transparansi, kesesuaian, kredibilitas, daya tarik, dan power dan variabel sales promotion yaitu kupon, penurunan harga, premium dan sampel adalah reliabel dengan variabel minat beli yaitu ketertarikan, keinginan dan keyakinan karena memiliki nilai Alpha Cronbach lebih dari 6,0. Terdapat pengaruh signifikan sebesar 71,6\% pada brand ambassador dan sales promotion terhadap minat beli smartphone LG G7 ThinQ oleh fans BTS di Jakarta Barat. Hal ini dapat dikatakan kemampuan variabel-variabel independen (brand ambassador dan sales promotion) dalam mempengaruhi variabel dependen (minat beli) cukup kuat karena nilai koefisien determinasi mendekati satu. Berdasarkan hasil koefisien determinasi di atas, dapat juga dikatakan bahwa minat beli LG G7 ThinQ dipengaruhi sebesar $71,6 \%$ oleh brand ambassador dan sales promotion. Sementara itu sisanya $28,4 \%$ dipengaruhi oleh variabel-variabel lain. Berdasarkan pedoman derajat keputusan nilai R, nilai Pearson Correlation dari 
variabel X1, X2 terhadap Y menunjukan nilai 0.846 yang berarti memiliki nilai korelasi sempurna karena termasuk dalam nilai Pearson Correlation 0.81 s/d 1.00. Besarnya pengaruh variabel brand ambassador BTS dan sales promotion terhadap minat beli smartphone LG G7 ThinQ memiliki hasil uji koefisien korelasi yang menunjukan Sig. F Change $0.000<0.05$. Hal ini berarti memiliki hubungan korelasi atau saling berhubungan, sehingga dapat disimpulkan bahwa setiap peningkatan pada nilai variabel $\mathrm{X}$ maka nilai pada variabel $\mathrm{Y}$ pun akan meningkat begitu juga sebaliknya, dimana setiap penurunan pada nilai variabel $\mathrm{X}$ maka nilai pada variabel Y pun akan menurun.

\section{Ucapan Terima kasih}

Terima kasih kepada Bapak Drs. Suherman Kusniadji, MM, M.I.Kom., selaku dosen pembimbing dan Ibu Lusia Savitri Setyo Utami, S.Sos., M.Si. selaku co. dosen pembimbing penulis. Kepada orang tua, keluarga, dan teman-teman penulis yang selalu mendukung dan memotivasi penulis selama berlangsungnya kegiatan penelitian.

\section{Daftar Pustaka}

Ikhsan, Putra Muhammad, Suharyono dan Abdillah, Yusri. (2014). Pengaruh Brand Ambassador Terhadap Brand Image Serta Dampaknya Terhadap Keputusan Pembelian (Survey pada pengguna LINE di Asia). Jurnal Administrasi Bisnis (JAB), Vol. 12, No. 1, halaman: 1-10

Sugiyono. (2013). Metodelogi Penelitian Kuantitatif, Kualitatif Dan R\&D. Bandung: ALFABETA 